DOI : $10.24260 /$ khatulistiwa.v8i2.1161

\title{
FORMS AND MEANINGS OF TRADITIONAL FOODS IN TANJUNG VILLAGE COMMUNITY, MEMPAWAH, WEST KALIMANTAN
}

\author{
Farninda Aditya \\ IAIN Pontianak Library \\ Email: nindaaditya@gmail.com
}

\section{HIGHLIGHT}

- $\quad$ Structure and Meaning of Language

- Traditional Culinary, Malay of Mempawah West Kalimantan

\section{ARTICLE HISTORY}

$\begin{array}{lll}\text { Submitt } & : & \text { 08 June } 2018 \\ \text { Revision } & : & \text { 20 July } 2018 \\ \text { Revision } & : & 5 \text { Aug } 2018 \\ \text { Minor } & & \\ \text { Accepted } & : & \text { 16 Aug } 2018 \\ \text { Published } & : & \text { 2 Sept } 2018\end{array}$

Keywords:

\begin{abstract}
Traditional culinary is a legacy of regional wealth. From its creation it is taught from generation to generation. From the mention of its name, the name traditional food is a local language that preserves traditional languages. Traditional culinary is also closely related to tradition and special day. Traditional food has certain functions and meanings from that special day. The village of Tanjung Mempawah is a Coastal Village in Mempawah Hilir District. This village has a variety of traditional foods that are still entrenched. These foods are also served on certain days. The language used by the people of Tanjung Village is Malay. This study discusses the Forms and Meanings of Traditional Foods in Kampung Tanjung Mempawah Community.
\end{abstract}

Structure and Meaning, Traditional Culinary, Local Culture, Mempawah

(C)2018 Khatulistiwa All Rights Reserved
KHATULISTIWA: Journal of Islamic Studies Vol. 8, No. 2. September 2018
DOI: $10.24260 /$ khatulistiwa.v8i2.1161

Form and Meanings of Traditional Foods in Tanjung Village Community, Mempawah, West Kalimantan 


\section{A. INTRODUCTION}

Every regions have traditional foods as their characteristics. Traditional food is a wealth of regions because it is inherited from generation to generation. Likewise, the mention of the names of these foods becomes part of the preservation of local languages. According to Kadarisman (2010) stated that language is a cultural entity and suggests that cultural concepts may be very specific and appear clearly through language expression. From language expressions, a new language or reference is created from the language that has ever existed. This can be seen from the comparison of the form and taste of food. The form and taste can be same, but they have a different name, for example the name of traditional cake, Lepat, in Mempawah Malay, this food is a type of everyday cake made from rice flour and banana. The food is wrapped in a banana leaves, which is folded on the right and left ends also facing down. This type of food, in Sambas Malay, is called Ukal. From naming of Ukal and Lepat, it is not only one type of banana food, but there is also made from sweet potatos and only rice flour, if it follows the basic ingredients, so the name of this food becomes Lepat Banana, Lepat Ubi, and Lepat Malas.

From these types of food if it is viewed from the elements of the words, the name of the food comes from Verbs, word 'Lipat' is followed by Noun 'Banana', and 'Ubi', but Lepat Malas is a combination of Verb+Adjective.

Tanjung is a village in Mempawah Hilir sub-district. Its position between Tanjung Laut Mempawah (Kuala) and it becomes the basic of the area's name. Kampung Tanjung has a tradition of Tolak Bale Poko Bulo. It is the moment to commemorate the history of the village. In this event, many various types of traditional food are served. In addition, like the tradition of Robo'robo' in Mempawah,

KHATULISTIWA: Journal of Islamic Studies Vol. 8, No. 2. September 2018
DOI: 10.24260/khatulistiwa.v8i2.1161

Form and Meanings of Traditional Foods in Tanjung Village Community, Mempawah, West Kalimantan 
people in the village also carry out it as well as eating together at the mosque in two Islamic holidays namely Eid Al-Fitr and Eid al-Adha.

In his writing, Fathan (2017) explains that Saprah or Makan Bersaprah is an event of eating together with some foods arranged in such a way without a table, with a base of modern cloth, and the dishes is called Saprahan. From the tradition of eating saprah in this village, there are various types of food, both Islamic holiday, daily meals, and snacks. The mention of food names also varies. From the name of the previous food (Lepat) it became one of the examples of traditional food names that showed the uniqueness of the language possessed by the people of Tanjung Mempawah. This becomes interesting to examine from the formation and meaning of traditional food of the community in Tanjung Mempawah Village.

In this study, the formation and meaning of the words of traditional food in Kampung Tanjung community were analyzed by Linguistics, namely Morphology, Syntax, and Semantics. Masnur (2009) said that morphemes as a form of integration are usually called basic forms. The basic form can experience the morphological process, affixation (affixing), Reduplication (Repetition), And Compounding (Composition). This affixation process according to Susilo (2010) resulted in changes in the meaning of language. Changes in the meaning of language are occurred because the changes in the form of words.

\section{B. METHOD}

This research is a qualitative research with descriptive method. Data obtained through interviews, and observations. The researcher took part in the Tolak Bala' and eating meals activities with saprahan and communicated directly with the population to find out the spoken language used. This activity was at the same time when the researcher became a field executive Technical Guidance for Participatory Traditional

KHATULISTIWA: Journal of Islamic Studies Vol. 8, No. 2. September 2018
DOI: 10.24260/khatulistiwa.v8i2.1161

Form and Meanings of Traditional Foods in Tanjung Village Community, Mempawah, West Kalimantan 
Culinary Data carried out by LIPI, in collaboration with Be-Kraf and LP2M IAIN Pontianak.

In this study, the object is the word or name of traditional food. The vocabulary formation of the name can be seen from the affixation to the name, and the merging of Nouns (N), Verbs (V), Adjective (Adj), and local words. The meaning of traditional food is not only from its lexical meaning but also enters the Semantics function of traditional food.

\section{RESULT AND DISCUSSION}

\section{General Description of Tanjung Village}

Tanjung village is a village located in Mempawah Hilir District. At present Malays form the majority of the population in Tanjung Village, although at first this village was inhabited by Bugis from Luwu, South Sulawesi (Farninda, 2016). The Bugis were Opu Daeng Ibrahim bin Opu Daeng Djamaluddin. The arrival of Daeng Brahima's people to Mempawah was to spread Islam (Farninda, 2014) who then had to find a place to live. The residence must be suitable for planting coconut. Although historically this village was formed by Bugis, this community speak with Malay language. Bugis community are found only few people and the others are passive speakers.

Besides Malay (Bugis descendants) in Tanjung village, there is Madurese community. Communication with Madurese in general is using Malay language, which also interferes with mixing code in communicating.

According to Yusriadi (2010) Bugis people crossed marriage with other residents (Malays) and give birth a different new generation. They do not practice

KHATULISTIWA: Journal of Islamic Studies Vol. 8, No. 2. September 2018
DOI: 10.24260/khatulistiwa.v8i2.1161

Form and Meanings of Traditional Foods in Tanjung Village Community, Mempawah, West Kalimantan 
Bugis tradition, nor they preserve Bugis language. This also happened to the community of Tanjung village, Mempawah.

This village has a tradition of Tolak Bala Pokok Bulo carried out on Thursday, Syafar 4th,1112 Hijriyah or 1772 BC, until nowadays. The age of Tanjung Village has reached 237 years. This ritual is carried out by the elder people in the village in praying to God, so that the village is kept away from disaster (Farninda, 2016b).

Tanjung village is in Mempawah district. The geographical position is the origin name of this village. Many villages are planted with coconut and banana trees. In general, coconut farm is intended to produce Kelapa Kereng or generally called Copra, then sold to Tengkulak (distributor), which is called Toke by local person. Bananas are sold in whole form or per bunch.

The position of the resident houses is facing each other. Behind the house there are coconut farms and also intercropping with bananas. There are many coconut farms in this village. It is no wonder there are many streams called Paret (ditcesh).

Tanjung village consists of six RTs and four RWs. The village is bordered by Secapah, Kuala Secapah Village and Mengkacak, Terusan Village. Eventhough, as coastal communities, there are not many residents who work as fishermen. Residents who become fishermen are currently known only two people. The activities of fishing or crab fishing are part-time activities.

Most of the women in Tanjung village are housewives. However, in their daily lives, some of them are also make cakes for sale. Some help their husbands to take wages of making copra. Housewives who join PKK, Posyandu, and Islamc recitaion members. Some also work as civil servants.

KHATULISTIWA: Journal of Islamic Studies Vol. 8, No. 2. September 2018
DOI: 10.24260/khatulistiwa.v8i2.1161

Form and Meanings of Traditional Foods in Tanjung Village Community, Mempawah, West Kalimantan 


\section{Previous Research}

Research on food or culinary interests is interesting. In the study of Wiwik Sundari (2008) entitled The Process of Forming the Names of English-Language Food Menu at Simpang Lima Restaurant, the results showed that 200 names of food menus were collected, 40 words experienced a derivation process, 22 words experienced an inflection process, 9 words included coinage, 24 words in the conversion category, 56 words in the form of borrowing, 14 words including compounding, 5 words in the form of acronyms and initialization, 3 words of back formation, 16 words in the form of clipping, and 4 words of blending. Wiwiek also traces the phrase elements in her research, and produces 200 noun phrases; 6 includes determiners+nouns, 29 pure adjectives+nouns, 50 derivatives + nouns, 113 nouns + nouns, and 2 noun phrases formed genetically + nouns. The phrases type of menu names is obtained by 1 type, namely nouns numbering 200.

Furthermore, the research by Sobari (2011) is the Form and Meaning of the Names of Traditional Foods in Purbalingga Regency. This research shows that formation occurs including basic words and derivative words consisting of words that are affixed, repeated words, and compound words. Then formations occur in the form of phrases based on endocentric attributive and nominal phrases. Based on the lingual satual, it is in the form of $\mathrm{N}+\mathrm{N}, \mathrm{N}+\mathrm{V}, \mathrm{N}+\mathrm{Ad}, \mathrm{V}+\mathrm{V}$. The meaning of food consists of Lexical, Grammatical, and Cultural meanings.

Eis Saputri (2016) examines Vocabulary in the Traditional Food of Pontianak Malay. The research aimed in examining Pontianak Malay traditional food vocabulary resulted in 49 traditional food vocabulary in the form of materials, 23 vocabulary in the form of tools, 16 forms of making, 14 forms of vocabulary, 10 color vocabulary, and 36 Pontianak Malay traditional food vocabulary.

KHATULISTIWA: Journal of Islamic Studies Vol. 8, No. 2. September 2018
DOI: 10.24260/khatulistiwa.v8i2.1161

Form and Meanings of Traditional Foods in Tanjung Village Community, Mempawah, West Kalimantan 
From the research, no one has written about the Formation and Meaning of Traditional Food in Tanjung communtity, Mempawah. The research on Food Naming of Malays in Tanjung Village, Mempawah has been conducted by Farninda Aditya in 2016. This study discusses Naming based on background, based on sources, the naming process of Malays. The results of the study do not discuss the naming of traditional foods.

\section{Traditional Food of Tanjung Village Community, Mempawah}

Traditional Food of Tanjung Community, Mempawah is divided into particular meals, daily meals and cakes/Tambol. Special Food is the food that only made at certain moments; for examples during Lebaran, marriage, or death events. While daily food means food that is usually served or found in everyday life. This list of foods can be seen in the following table.

Table 1. Particular Meals

\begin{tabular}{|l|l|l|}
\hline No. & Food Name & Food Description \\
\hline 1 & Bontong & $\begin{array}{l}\text { Foods made from pulut/ white sticky rice and } \\
\text { coconut milk, wrapped in young banana and old } \\
\text { banana leaves, long shape and then tied with a } \\
\text { rope. Bontong skin is called Blesong }\end{array}$ \\
\hline 2 & Pat Lau & $\begin{array}{l}\text { The food is made from pulut / white sticky rice } \\
\text { and coconut milk, which is wrapped in young } \\
\text { banana and old banana leaves, the bar contains } \\
\text { pulut with young banana leaves whose ends are } \\
\text { folded in triangle shape, and put together like a } \\
\text { bar, about 6 pieces. }\end{array}$ \\
\hline
\end{tabular}

KHATULISTIWA: Journal of Islamic Studies Vol. 8, No. 2. September 2018
DOI: 10.24260/khatulistiwa.v8i2.1161

Form and Meanings of Traditional Foods in Tanjung Village Community, Mempawah, West Kalimantan 


\begin{tabular}{|c|c|c|}
\hline 3 & Ketupat Aek & $\begin{array}{l}\text { It is made from rice. The skin is woven from the } \\
\text { leaves of a young coconut or janur leaves. }\end{array}$ \\
\hline 4 & Ketupat Lemak & $\begin{array}{l}\text { It is made from white sticky rice and boiled with } \\
\text { coconut milk. Be wattled with young coconut or } \\
\text { janur leaves. The shape of the nest on the } \\
\text { diamond wing is a little humble. The middle part } \\
\text { appears rather arise. }\end{array}$ \\
\hline 5 & Pajeri Nenas & $\begin{array}{l}\text { It is a vegetable soup made from vegetables and } \\
\text { cooked with various spices and coconut milk. }\end{array}$ \\
\hline 6 & Pajeri Terong & $\begin{array}{l}\text { It is a vegetable soup made from eggplant and } \\
\text { cooked with various spices and white coconut } \\
\text { milk. }\end{array}$ \\
\hline 7 & Ayam Masak Puteh & $\begin{array}{l}\text { It is a basic dish cooked with various spices and } \\
\text { some coconut milk. }\end{array}$ \\
\hline 8 & Ayam Berempah & $\begin{array}{l}\text { It is a basic dish cooked with various spices and } \\
\text { yellow coconut milk. At a glance. it likes an Opor } \\
\text { Chicken soup, but it is not served in onewhole } \\
\text { chicken, but it has been cut into pieces. }\end{array}$ \\
\hline 9 & Udang Sambal Serai & $\begin{array}{l}\text { It is made from dried shrimp with various spices, } \\
\text { with more lemongrass bulbs. Lemongrass bulbs } \\
\text { are thinly sliced and then fried dry, and pounded. } \\
\text { The aroma of lemongrass and chilli becomes a } \\
\text { typical aroma of this food. }\end{array}$ \\
\hline 10 & Ikan Pindang & $\begin{array}{l}\text { Pindang fish (smoked fish) commonly used is } \\
\text { tuna fish. It is sliced in big slices. One tail size } 2 \mathrm{~kg} \\
\text { usually produces } 6 \text { slices. Cooking these fish } \\
\text { requires a long time of around } 1-4 \text { hours to soften } \\
\text { the bones on low heat. Coconut water with sugar } \\
\text { cane slices is typical of this food. }\end{array}$ \\
\hline 11 & Srikaye & $\begin{array}{l}\text { It is made from eggs and sugar. It is Shaken, } \\
\text { filtered, then steamed. Srikaye, that is ripe, } \\
\text { produces brown color. This food is usually a } \\
\text { companion for eating Bontong and Pat Lau. }\end{array}$ \\
\hline
\end{tabular}

KHATULISTIWA: Journal of Islamic Studies Vol. 8, No. 2. September 2018
DOI: 10.24260/khatulistiwa.v8i2.1161

Form and Meanings of Traditional Foods in Tanjung Village Community, Mempawah, West Kalimantan 


\begin{tabular}{|l|l|l|}
\hline 12 & Sagon Telok & $\begin{array}{l}\text { It is made from eggs and sugar. However, it is } \\
\text { made in a pan that must be stirred continuously } \\
\text { so that it turns into flour. The taste of this food is } \\
\text { sweet. }\end{array}$ \\
\hline 13 & Sagon Bakar & $\begin{array}{l}\text { Burn Sagon comes from Kanji flour and grated } \\
\text { coconut. Usually the coconut used is War coconut, } \\
\text { which is half-old coconut. This food is baked or } \\
\text { burned. }\end{array}$ \\
\hline 14 & $\begin{array}{l}\text { It is made from white sticky rice which has been } \\
\text { roasted until dry, then machined to become sticky } \\
\text { rice flour. This flour is cooked with sugar water } \\
\text { and coconut milk until it thickens to dodol. The } \\
\text { characteristic of dodol is wrapped or formed with } \\
\text { Opek, the lower midrib of areca leaves. }\end{array}$ \\
\hline 15 & $\begin{array}{l}\text { Types of drinks mixed with a variety of red spices. } \\
\text { These drinks originate from Sepang skin. Air } \\
\text { Serbat is known as Aek Penguser. }\end{array}$ \\
\hline
\end{tabular}

Table 2 Daily Meals

\begin{tabular}{|l|l|l|}
\hline No & Food Name & Food Description \\
\hline 1 & To'ol & $\begin{array}{l}\text { It is made from cassava leaves, which in the local } \\
\text { language is called Ubi Kayuk and Ubi Nggale. These } \\
\text { leaves are stacked, then sauteed with coconut } \\
\text { milk. Usually mixed with pipette eggplant, a type } \\
\text { of small eggplant fruit, round in its shape. }\end{array}$ \\
\hline 2 & Botok & $\begin{array}{l}\text { It is made from fish basic, noni leaves, spices and } \\
\text { turmeric leaves. Noni leaves wrap fish and spices, } \\
\text { turmeric leaves, then it is shaped like a square and } \\
\text { tied with ropes. }\end{array}$ \\
\hline 3 & Lawar & $\begin{array}{l}\text { It is made from vegetables, usually pegage and } \\
\text { long beans, thinly sliced and then mixed with }\end{array}$ \\
\hline
\end{tabular}

KHATULISTIWA: Journal of Islamic Studies Vol. 8, No. 2. September 2018
DOI: 10.24260/khatulistiwa.v8i2.1161

Form and Meanings of Traditional Foods in Tanjung Village Community, Mempawah, West Kalimantan 


\begin{tabular}{|c|c|c|}
\hline & & $\begin{array}{l}\text { grated coconut which has been burned for a while. } \\
\text { It is white. }\end{array}$ \\
\hline 4 & Urap & $\begin{array}{l}\text { It is made from vegetables, such as pegage leaves, } \\
\text { noni, and betek flowers. The vegetables are thinly } \\
\text { sliced and the flower is cut around the index } \\
\text { finger. Then it is mixed with grated coconut which } \\
\text { has been seasoned with various spices, chillies } \\
\text { and brown sugar. Urap color is light brown, or in } \\
\text { the local language is called red. }\end{array}$ \\
\hline 5 & $\begin{array}{l}\text { Sayok Lemak Buas- } \\
\text { buas }\end{array}$ & $\begin{array}{l}\text { The basic ingredient is Buas-buas leaves. In } \\
\text { Sambas language called Singkil. The leaves are } \\
\text { diced, then sauteed with coconut milk. It is usually } \\
\text { mixed with green beans. }\end{array}$ \\
\hline 7 & Petes & $\begin{array}{l}\text { It is made from dried shrimp skin, then pounded } \\
\text { and the water is filtered. The water is then cooked } \\
\text { to dry, producing juice from the pounded water. } \\
\text { Cooking petes is usually fried with onions and } \\
\text { mixed with oil and cayenne pepper. }\end{array}$ \\
\hline 8 & Ikan Asam Pedas & $\begin{array}{l}\text { It is made from fish basic which are sauteed with } \\
\text { fine chili and given a little water to make its sauce. }\end{array}$ \\
\hline 9 & Ikan masak kuning & $\begin{array}{l}\text { It is made from fish, which are fried with garlic, } \\
\text { onion, turmeric, and acidic water, and given a little } \\
\text { water to make its sauce. The color is yellow. }\end{array}$ \\
\hline 10 & Sayok Tumes & $\begin{array}{l}\text { Fried vegetables, in general, are vegetables fried } \\
\text { with onions, garlic and sprinkled with seasonings. } \\
\text { The usual fried vegetables are kangkong, sweet } \\
\text { potato or yam leaves and mustard greens. }\end{array}$ \\
\hline 11 & Sayok keladi & $\begin{array}{l}\text { Sayok Keladi is made from tendrils or local } \\
\text { languages call it sulur keladi, cooked like cooking } \\
\text { spicy sour fish and usually mixed with turmeric } \\
\text { leaf slices. }\end{array}$ \\
\hline 12 & Telok sambal asam & $\begin{array}{l}\text { Usually the eggs used are duck eggs. The fishy } \\
\text { aroma of duck eggs is not too flavorful when }\end{array}$ \\
\hline
\end{tabular}

KHATULISTIWA: Journal of Islamic Studies Vol. 8, No. 2. September 2018
DOI: 10.24260/khatulistiwa.v8i2.1161

Form and Meanings of Traditional Foods in Tanjung Village Community, Mempawah, West Kalimantan 


\begin{tabular}{|l|l|l|}
\hline 13 & $\begin{array}{l}\text { cooked with sour sauce and the egg shape is more } \\
\text { rounded. It contrasts with chicken eggs generally. }\end{array}$ \\
\hline 14 & Ikan Masak Kecap & $\begin{array}{l}\text { Smooth chili mashed with onions and garlic. Then } \\
\text { fried with oil, mixed with acidic water and sugar. } \\
\text { In making this chili, there must be a sour taste and } \\
\text { sweetness. Usually this sauce is used to mix fried } \\
\text { fish, fried eggs, and anchovy mixed with fried } \\
\text { soybean cake which is cut into small pieces }\end{array}$ \\
\hline 15 & $\begin{array}{l}\text { It is made from fried fish. Then it is fried with soy } \\
\text { sauce mixture. Usually it is different from stews. } \\
\text { The sauce is thinner with simple spices. }\end{array}$ \\
\hline Acar & Acan $/$ Telok & $\begin{array}{l}\text { The basic ingredients are usually fish or eggs. The } \\
\text { seasoning used is mixed hazelnut, onion, garlic } \\
\text { and turmeric. Then it is fried. It is usually mixed } \\
\text { with Perenggi chili. Pickled fish must be fried first, } \\
\text { then mixed with pickled spices. Usually the fish } \\
\text { used is bottom fish without being cut. Eggs are } \\
\text { usually boiled first, some are fried again and some } \\
\text { are not. }\end{array}$ \\
\hline
\end{tabular}

Tabel 3 Makanan Berbentuk Kue/Tambol

Table 3. Cake-shaped food / Tambol

\begin{tabular}{|l|l|l|}
\hline No. & \multicolumn{1}{|c|}{ Food Name } & \multicolumn{1}{c|}{ Food Description } \\
\hline 1 & Dokok-dokok & $\begin{array}{l}\text { It is made from pulut / white sticky flour mixed } \\
\text { with a little plain and lime water. Then it is } \\
\text { rounded up to form a Dokok-dokok unit. Then } \\
\text { mixed with coconut core. The core is grated } \\
\text { coconut mixed with coconut sugar / brown sugar, } \\
\text { whole pandan leaves until it pulverizes. } \\
\text { Furthermore dokok-dokok is wrapped with } \\
\text { banana leaves on the right end, then it is added to } \\
\text { the coconut milk juice and then folded. Then it is }\end{array}$ \\
\hline
\end{tabular}

KHATULISTIWA: Journal of Islamic Studies Vol. 8, No. 2. September 2018
DOI: 10.24260/khatulistiwa.v8i2.1161

Form and Meanings of Traditional Foods in Tanjung Village Community, Mempawah, West Kalimantan 


\begin{tabular}{|c|c|c|}
\hline & & $\begin{array}{l}\text { cooked it by steaming it. There are two dokok- } \\
\text { dokok, the usual and the naked dokok-dokok } \\
\text { which are without the use of young banana leaves. } \\
\text { The way to cook dokok-dokok is boiling it } \\
\text { immediately, raise it when it is arising, then put it } \\
\text { into coconut milk juice. }\end{array}$ \\
\hline 2. & Bena'am & $\begin{array}{l}\text { It is made from yams. They are boiled then } \\
\text { mashed, rounded and inside are filled with slices } \\
\text { of brown sugar or sugar. Then they are fried. }\end{array}$ \\
\hline 3 & Gamat & $\begin{array}{l}\text { It is made from cassava, which is grated then } \\
\text { formed flat, steamed, fried, then roasted with } \\
\text { granulated sugar. }\end{array}$ \\
\hline 4 & Kacemate & $\begin{array}{l}\text { It is made from bananas and sweet potatoes. } \\
\text { Bananas used in ancient times were banana } \\
\text { nipah or generally called banana kapok. These } \\
\text { bananas are not cut or chopped. Then it is } \\
\text { wrapped with grated sweet potatoes, wrapped in } \\
\text { banana leaves, steamed. After it is cooked, the } \\
\text { wrapper is opened, stirred with white grated } \\
\text { coconut mixed with salt, then it is cut. The round } \\
\text { shape of this piece is considered to be similar to } \\
\text { the shape of the eye. }\end{array}$ \\
\hline 5 & Tri Salat & $\begin{array}{l}\text { It is made from grated yams, then steamed. The } \\
\text { half-cooked yam is coated with a mixture of flour } \\
\text { which has been mixed with coconut milk and } \\
\text { coconut sugar / brown sugar. It is steamed again. } \\
\text { When it is sliced, it looks white and brown. }\end{array}$ \\
\hline 6 & Tri Mandik & $\begin{array}{l}\text { It is made from rice flour mixed with a little plain } \\
\text { and lime water. Then shaped it round, and } \\
\text { flattened in the middle. Next, boiled and rained it. } \\
\text { Then mixed it with coconut milk which has been } \\
\text { mixed with brown sugar the cooked them } \\
\text { together. }\end{array}$ \\
\hline 7 & Ati Parik & $\begin{array}{l}\text { It is made from rice flour. Rice flour mixed with } \\
\text { plain water and a little suji water. Suji is a type of }\end{array}$ \\
\hline
\end{tabular}

KHATULISTIWA: Journal of Islamic Studies Vol. 8, No. 2. September 2018
DOI: 10.24260/khatulistiwa.v8i2.1161

Form and Meanings of Traditional Foods in Tanjung Village Community, Mempawah, West Kalimantan 


\begin{tabular}{|c|c|c|}
\hline & & $\begin{array}{l}\text { leaf used for coloring. The color is green. The } \\
\text { leaves are pounded, and filtered to get the water. } \\
\text { Then it is cooked or in local language is uli, until } \\
\text { cooked. Then cool in a container. After being cold, } \\
\text { sliced and mixed it with coconut milk sauce mixed } \\
\text { with sugar water like Tri Mandik sauce. }\end{array}$ \\
\hline 8 & Sopok Pelopok & $\begin{array}{l}\text { These foods are usually seasonal food, namely the } \\
\text { durian season. Durian is mixed with coconut milk } \\
\text { and brown sugar like Tri Mandik sauce. Side by } \\
\text { side for this sauce is steamed white rice / pulut. It } \\
\text { is usually served in the form of a small bowl. } \\
\text { Doused with gravy sopok pelopok sauce into the } \\
\text { cup. }\end{array}$ \\
\hline 10 & Serawe Melewah. & $\begin{array}{l}\text { The sauce is the same as tri mandik, which is a } \\
\text { mixture of coconut milk and brown sugar. } \\
\text { Melewah becomes the basic ingredient for } \\
\text { assisting meals. Melewah is sliced in dice shape, } \\
\text { then it is mixed with the sauce. It is usually } \\
\text { seasonal meal, such as Melewah season in fasting } \\
\text { month. }\end{array}$ \\
\hline 11 & Serawe Kuini & $\begin{array}{l}\text { Like Sopok Pelopok, Kuini is cooked with coconut } \\
\text { milk and brown sugar. It is not only durian, but } \\
\text { also kuini fruit. It is also eaten with steamed sticky } \\
\text { rice. }\end{array}$ \\
\hline 12 & Jempot-jempot & $\begin{array}{l}\text { It is made from banana fruit. The bananas used are } \\
\text { nipah bananas that have been damaged or } \\
\text { matured. It is mashed then mixed with wheat } \\
\text { flour or local language called tepong gendom. Then } \\
\text { it is fried with the help of a tablespoon. In the past, } \\
\text { the mixture was picked up by hand so that it was } \\
\text { called jempot-jempot. }\end{array}$ \\
\hline 13 & Bingke Beras & $\begin{array}{l}\text { It is made from rice flour mixed with coconut } \\
\text { milk and brown sugar. Then the rice flour is put } \\
\text { into the mixture until it blends with the previous } \\
\text { mixture. Next, it is burned with a bingke flower }\end{array}$ \\
\hline
\end{tabular}

KHATULISTIWA: Journal of Islamic Studies Vol. 8, No. 2. September 2018
DOI: 10.24260/khatulistiwa.v8i2.1161

Form and Meanings of Traditional Foods in Tanjung Village Community, Mempawah, West Kalimantan 


\begin{tabular}{|l|l|l|}
\hline & & $\begin{array}{l}\text { print. The molded petals in the local language are } \\
\text { called takok. }\end{array}$ \\
\hline 14 & Lepat Malas & $\begin{array}{l}\text { Lepat Malas is made from rice flour mixed with } \\
\text { brown sugar and a little water. It is wrapped in } \\
\text { banana leaves and the left right end is folded. } \\
\text { Then, it is steamed. }\end{array}$ \\
\hline 15 & Batang Burok & $\begin{array}{l}\text { Batang Burok is made from flour mixed with water } \\
\text { and eggs. Then, it is cooked with the help of a pan } \\
\text { or teplon, and it producse flour skin. Next, it is } \\
\text { filled with coconut core, it can also sugar then it is } \\
\text { rolled. }\end{array}$ \\
\hline
\end{tabular}

\section{Word Formation Analysis}

From data obtained, the word formation of food is known as the basic word experiencing affixation and there are repeated words, compound words, and parables. Affixation to the form of food names is as follows, as a set of food names only found one food name, which is prefix ber-. Foods that experience prefixes are Ayam Masak Berempah. Berempah, the basic word is rempah. The food name of Be'nama is also experiences a prefix, because there are also some who say the name of this food is only $\mathrm{Na}^{\prime} \mathrm{am}$. In the Malay dialect, sometimes the letter (r) is lost. The prefix ber- does not eliminate the meaning of the name of the food, Ayam Masak Rempah. The repeat ed word on food names are found in the name of Dokok-dokok, Jempot-jempot, Buasbuas, and Sopok-pelopok. The compound word in the name of food is found in the word kacemate which comes from the word kacamata. Bingke Beras which is a combination of the words Bingke as the name of food and Beras (rice), the lexical meaning of rice is the rice that has been peeled off.

KHATULISTIWA: Journal of Islamic Studies Vol. 8, No. 2. September 2018
DOI: 10.24260/khatulistiwa.v8i2.1161

Form and Meanings of Traditional Foods in Tanjung Village Community, Mempawah, West Kalimantan 
This form of food is not bingke in the form of rice, or whole rice is the basic ingredient, but the basic ingredients have been processed into flour. The parable word on food occurs in Burok Batang. This rectangular cake, the outer skin is not smooth, and usually there are bubble marks. The core color is also visible, like a weathered stem.

In the word formation of this traditional food name consists of various elements. In this case the noun $(\mathrm{N})$ can be a name for food. Likewise, the Adjectives (Adj), and the verb (V).

The word element in the food name consists of two units with elements from $\mathrm{N}+\mathrm{N}$, namely;

1) $\operatorname{Ketupat}(N)+\operatorname{Lemak}(N)$

2) $\operatorname{Ketupat}(N)+\operatorname{Aek}(N)$

3) Fish (N) + Pindang $(N)$

4) Sagon $(N)+\operatorname{Telok}(N)$

5) Dodol (N) + Cengkarok (N)

6) Sayok $(N)+$ Tumes $(N)$

7) Sayok $(N)+$ Keladi $(N)$

8) $\operatorname{Aek}(N)+\operatorname{Serbat}(N)$,

9) Sagon (N) + Bakar (V)

10) $\operatorname{Ikan}(N)+\operatorname{Acar}(N)$

11) $\operatorname{Telok}(N)+\operatorname{Acar}(N)$

12) $\operatorname{Ati}(N)+\operatorname{Parik}(N)$

13) Bingke (N) + Beras (N)

The word element in the food name consists of two units with elements from $\mathrm{N}+$ Adj, namely:

1) Sambal (N) + Manis (Adj)

2) Batang (N) + Buruk (Adj)

3) Lepat (N) + Malas (Adj)

KHATULISTIWA: Journal of Islamic Studies Vol. 8, No. 2. September 2018
DOI: 10.24260/khatulistiwa.v8i2.1161

Form and Meanings of Traditional Foods in Tanjung Village Community, Mempawah, West Kalimantan 
The word element in the food name consists of three units with elements from $\mathrm{N}+\mathrm{N}+$ Adj, namely:

1) Sayok (N) +Lemak(N) + Buas-buas basic word 'Buas '(Adj)

2) Telok (N), Sambal (N) + Asam (Adj)

The word element in the food name consists of three units with elements from $\mathrm{N}+\mathrm{N}+\mathrm{N}$, namely:

Udang $(N)+$ Sambal $(N)+$ Serai $(N)$

The word element in the food name consists of three units with elements from $\mathrm{N}+$ Adj+Adj, namely:

Ikan (N) + Asam (Adj) + Pedas (Adj)

The word element in the food name consists of three units with elements from $\mathrm{N}+\mathrm{V}+\mathrm{N}$, namely:

1) $\operatorname{Ikan}(N)+\operatorname{masak}(V)+$ kuning $(N)$

2) $\operatorname{Ikan}(N)+\operatorname{Masak}(V)+\operatorname{Kecap}(N)$

3) Ayam (N)+Masak (V) + Puteh (N)

4) $\operatorname{Ayam}(N)+\operatorname{Masak}(V)+\operatorname{Rempah}(N)$

\section{Name Formation Based on the Meaning}

Some food names cannot be known including N, V, or Adj. In this case, the local word which is unknown becomes a new word in the local vocabulary of Malay. Bontong is a traditional food like Lontong, a Javanese food. However, what distinguishes Bontong from Lontong is the basic ingredients, and the packaging. If Lontong, to cover the tip is by flanking the left and right sides of the tip with a small stick, with the help of a rope, which is then tied per segment until thoroughly. If from the shape, the name of Bontong comes from the word Buntung. Because, the rest of the leaves on the right and left ends are folded and wrapped around the rope so that it looks like it was cut off.

Pat Lau in the spoken language mentioned, this food is called Pat Lau in the vocabulary words. The lexical words of Pat Lau in KBBI is not found. However, when

KHATULISTIWA: Journal of Islamic Studies Vol. 8, No. 2. September 2018
DOI: 10.24260/khatulistiwa.v8i2.1161

Form and Meanings of Traditional Foods in Tanjung Village Community, Mempawah, West Kalimantan 
it is viewed from its shape, this food is made from the basic ingredients of white sticky rice wrapped in banana leaves and folded many times. First, when forming halfcooked sticky rice on the leaves, the leaves must be folded, so that it is flat and then reopened. At the ends, it is folded like making Nagasari and the rest of the middle end is folded again. This food is usually a substitute for rice. Companions for this food are side dishes. Referring to PatLau's companion, Lau comes from the word Lauk, so that it becomes lepat which is eaten with side dishes because generally Lepat tastes sweet.

Serikaye in KBBI is written by Serikaya. As Malay 's spoken language, Srikaya became Serikay [e]. In KBBI, Serikaya is a food comes from eggs, coconut milk and sugar. Petes in KBBI was written by Petis in Malay's spoken language Petis as Pet [e]. In KBBI, Petis is made from freshly pounded fresh shrimp, boiled merang ash water and spiced with black, thick, and pungent ash merang.

Lawar in KBBI was written by Lawar. In spoken language, the word is the same, namely [lawa [?]. The meaning in KBBI, Lawar is an incision (N) or pieces of meat or fish. Referring to the incision, the name of lawar food is formed. In the Malay community, lawar which is slashed are vegetables.

In KBBI, urap means spiced grated coconut for a mixture of vegetables, sweet potatoes, sticky rice, and so on. This is the same as urap for the Tanjung community, which is coconut mixed with boiled vegetables. Tri Salat, the word 'Tri' comes from the word Putri in the spoken language become Tri. The word Putri is used, as a parable, that foods that use a lot of eggs and sugar are high social status. While salad can be derived from the word Sulat. In the Tanjung community, the word 'sulat' means Lapis. Like a leaky roof, it can be sulat (layered). In KBBI, this word is written salut, menyaluti which means layering. This food is made by coating, steaming cassava with a mixture of flour and mixed by brown sugar and coconut milk.

KHATULISTIWA: Journal of Islamic Studies Vol. 8, No. 2. September 2018
DOI: 10.24260/khatulistiwa.v8i2.1161

Form and Meanings of Traditional Foods in Tanjung Village Community, Mempawah, West Kalimantan 
Tri Mandi, the word 'Tri' has the same meaning with Tri on the word 'Tri Salad'. 'Mandi' in the word as a parable that flour spheres soak in sugar-coconut milk sauce ilk like a bath.

Dokok-dokok, in KBBI this word already has the meaning of cakes made from rice flour, coconut, sugar, and bananas wrapped in banana leaves and steamed. When compared to Dokok-dokok in Tanjung community, its meaning refers to Lepat Banana. Before it is mixed with coconut core, the food is formed a fist with one hand. The shape of the fist forms a fold of fingers. In Tanjung community, a finger fold is called Bukuk. Referring to the form, the word 'Dokok' is similar with the word 'Bukuk'. Examples of the sentence " Ni bukuk-bukuk tangan ni kakuk rase $e$ ", meaning that these folds of the fingers feel stiff.

Gamat significantly in KBBI is sea cucumber. It is seen from the form of Gamat on traditional food of Tanjung community. It is a long flat shape, with brownish brown piles of sugar after frying process. Tanjung community, which originated from Bugis and Bugis and Bugis descendant were known for their skill in fishing. Sea cucumbers in the sea as a parable that this food is similar with the sea cucumber. Geographically, Tanjung village is in the coast.

Batang Burok is a parable word on food occurs in Batang Burok (damaged wood). The cake is rectangular form. The outer skin is not smooth. It is usually there are bubble marks. The core color is also visible like a weathered stem. Burok is a word that means the same as bad which is damaged.

Sayok Lemak Buas-buas, the phrase 'sayok lemak' has the meaning of vegetables contain fat. The fat comes from coconut milk. Buas-buas is the name of a tree found in the forest. This tree is not planted by the community. The leaves of this

KHATULISTIWA: Journal of Islamic Studies Vol. 8, No. 2. September 2018
DOI: 10.24260/khatulistiwa.v8i2.1161

Form and Meanings of Traditional Foods in Tanjung Village Community, Mempawah, West Kalimantan 
plant are usually eaten by animals. Therefore, it may be the name for the tree namely plants eaten by wild animals. Buas in KBBI means fierce and wild.

Jempot-jempot, the word Jempot means picking up. Before frying, the mixture is picked up by hand and then put into a pan to fry. The shape is bigger than the current shape which is picked up with a table spoon.

There are many words in the name of traditional food that have no meaning namely To'ol, Serawe, Pajeri, Na'am, and Sopok Pelopok. There was an attempt by the community to give an explanation of the names but their explanation is seemed like their guesses.

\section{Semantic Function}

Beside the meaning of food that was previously delivered lexically and parable mentioned above, there is also a function of the meaning of the food. Semantic function in the traditional food of Tanjung village community are explain as follows:

1) Semantic function of food for particular days: Lebaran day, Tolak Bala, and Robo-robo'

a. Rice alternative food:

Ketupat Aek, Ketupat Lemak, Bontong, Pat Lau, Ikan Acar, Telok Acar, Ikan Masak Kecap

b. Side Dishes:

Ayam Masak Puteh, Ayam Masak Berempah, Udang Sambal Serai, Ikan Pindang, Lawar, Urap

c. Cakes/Tambol/Snacks:

Serikaya, Sagon Telok, Sagon Bakar, Dodok Cengkarok

d. Drinks:

Aek Serbat

2) Semantic Function of Daily Meals

a. Side Dishes

KHATULISTIWA: Journal of Islamic Studies Vol. 8, No. 2. September 2018
DOI: 10.24260/khatulistiwa.v8i2.1161

Form and Meanings of Traditional Foods in Tanjung Village Community, Mempawah, West Kalimantan 
To'ol, Botok, Petes, Telok Sambal Manis, Sambal Manis, Ikan Masak Kuning, Sayok Lemak Buas-buas, Sayok Tumes, Sayok Keladi, Ikan Masak Kecap.

b. Cakes/Tambol/Snacks

Dokok-dokok, Kacemate, Tri Salat, Bena'am, Gamat, Jempot-jempot

3) Semantic Function of Tanjung community traditional food based on a certain time

The certain time in this case is seasonal time, such as the rainy season, fruit season and fasting month. In general, this food can be a daily meal, but often found at certain times

a) Rainy Season

In this season, food in the form of cakes which in the community call a tambol commonly found are Ati Parik and Tri Mandi. They are type of sauced food. This food is eaten when it is warm.

b) Fruit Season

Some types of fruit trees do not always bear every time. Foods from fruit made by people in Tanjung villages come from Durian and Kuini Fruit. Foods mixed with Durian are called Sopok Pelopok and Kuini called Serawe Kuini.

Durian and Kuini fruits have a distinctive aroma. A pungent and spread aroma. Once, many family members were sometimes not comparable with food supplies. In order to the family members can eat the foods, then this food was processed into a drum.

c) Fasting month

Generally the particular foods are also served in the fasting month especially on the first fasting day. Daily foods such as side dishes and cakes can also be found in this month. However, the most common fruit is found in this month. Melewah is usually processed into a menu of breaking the fast namely Serawe Melewah besides Bingke Beras. In the fasting month, only certain people in Tanjung village sell these tambol.

KHATULISTIWA: Journal of Islamic Studies Vol. 8, No. 2. September 2018
DOI: 10.24260/khatulistiwa.v8i2.1161

Form and Meanings of Traditional Foods in Tanjung Village Community, Mempawah, West Kalimantan 


\section{CONCLUSION}

Traditional food shows the regional identity. From the name of the food, it can be known from its region. From food, the language used in the area is also known. Traditional food in Tanjung Mempawah community has many various names formation. Forms of words from food are known to have basic words that are affixed and there are repeated words, compound words, and parables.

The words formation of this traditional food has many various elements. $\mathrm{N}+\mathrm{N}$ elements are 13 food names, $\mathrm{N}+$ Adj elements are 3 food names, and $\mathrm{N}+\mathrm{N}+\mathrm{Adj}$ elements are 2 food names. $\mathrm{N}+\mathrm{N}+\mathrm{N}$ element is one food namely Udang Sambal Serai. $\mathrm{N}+$ Adj + Adj element which is Ikan (N)+Asam (Adj) + Pedas (Adj). N + V + N elements are 4 food names.

The result analysis of Meanings based names formation namely Bontong derived from the word Buntung. Pat Lau said Pat comes from the word Lepat, and Lau comes from the word Lauk. Serikaye, Petes, Lawar and Urap are words that have been found in KBBI. In Tri Salat, the word Tri comes from the word Putri, and Salat comes from the word Sulat. In KBBI this word is written salut, menyaluti which means layering. Tri Mandi, wheat flour round soak in the sauce made from sugar and coconut milk like soaking. Dokok-dokok refers to the form Bukuk in a local language which means finger folds. Gamat refers to sea cucumbers, Batang Burok is parables of damaged logs, Buas-buas for plants eaten by wild animals, and jempot-jempot is taken from its making process.

KHATULISTIWA: Journal of Islamic Studies Vol. 8, No. 2. September 2018
DOI: 10.24260/khatulistiwa.v8i2.1161

Form and Meanings of Traditional Foods in Tanjung Village Community, Mempawah, West Kalimantan 
Semantic functions of traditional food in Tanjung village community are divided for partcular days; Lebaran, Tolak Bala, and Robo'-Robo ', semantic function food for daily meals, and semantic function traditional food Tanjung village community Based on a certain time. Furthermore, the local words that have not known the meaning yet show that linguistic analysis of food names can be a further study.

KHATULISTIWA: Journal of Islamic Studies Vol. 8, No. 2. September 2018
DOI: 10.24260/khatulistiwa.v8i2.1161

Form and Meanings of Traditional Foods in Tanjung Village Community, Mempawah, West Kalimantan 


\section{BIBLIOGRAPHY}

Aditya, F.(2014). Tolak Bale Pokok Bulo Kampong Tanjong: Makalah. Dipresentasikan Lomba Karya Tuli Ilmiah Bagi Mahasiswa/Umum oleh Dinas Kearsipan dan Perpustakaan Kalbar, tanggal 26 Juni 2014.

Aditya, F. (2016). Penamaan Orang Melayu di Kampung Tanjung Mempawah,(Tesis).FKIP-Magister Pendidikan Bahasa Indonesia.Pontianak: Universitas Tanjungpura

Aditya, F. (2016b). Penamaan OrangMelayu di Pesisir Mempawah. Pontianak:STAIN Pontianak Press dan Club Menulis IAIN Pontianak

Alghifari, S. (2012). Bentuk dan Makna Nama-nama Makanan Tradisional di Kabupaten Purbalingga (Doctoral dissertation, Universitas Negeri Semarang).

David, dkk. (2016). KBBI V Offline. Badan Pengembangan dan embinaan Bahasa, Kementerian dan pendidikan dan Kebudayaan Republik Indonesia

Saputri, E., Sulissusiawan, A., \& Amir, A. (2016). Kosakata dalam Makanan Tradisional Masyarakat Melayu Pontianak. Jurnal Pendidikan dan Pembelajaran, 5 (8).

Masnur Muslich. (2009). Tata Bentuk Bahasa Indonesia: Kajian ke Arah Tatabahasa Deskriptif. Jakarta: Bumi Aksara

Susilo Mansurudin. (2010). Mozaik Bahasa Indonesia: Materi Bahan Ajar Bernuansa 'Ulul Albab'. Maliki Press: Malang

KHATULISTIWA: Journal of Islamic Studies Vol. 8, No. 2. September 2018
DOI: 10.24260/khatulistiwa.v8i2.1161

Form and Meanings of Traditional Foods in Tanjung Village Community, Mempawah, West Kalimantan 
Yusriadi. Ed. (2010). Bugis Perantauan. Pontianak: STAIN Pontianak Press dan Club Menulis STAIN Pontianak

Sundari, W. (2008). Proses Pembentukan Nama-nama Menu Makanan Berbahasa Inggris di Restoran di Simpang Lima, Doctoral dissertation, Program Pasca Sarjana Universitas Diponegoro.

KHATULISTIWA: Journal of Islamic Studies Vol. 8, No. 2. September 2018
DOI: 10.24260/khatulistiwa.v8i2.1161

Form and Meanings of Traditional Foods in Tanjung Village Community, Mempawah, West Kalimantan 